\title{
離散時間モデル規範形適応制御系の一設計法 ${ }^{\dagger}$
}

\author{
藤 井 省 三*・水，野 直 樹*
}

A Design Method for a Discrete Model Reference Adaptive Control System

Seizo FujI* and Naoki MızUno*

This paper presents a new method for designing a discrete model reference adaptive control (DMRAC) system by input synthesis adaptation. The controlled plant is a singleinput and single-output, continuous-time, linear plant. The control is performed by a digital computer. Liapunov's direct method is used to establish a parameter-adjustment law which ensures an asymptotic stability of the error signal. A sufficient condition of stability for the DMRAC system is clarified. The derived adaptive control algorithm can be implemented through a simple and systematic design procedure. In the implementation only available input-output data of the plant are used and no parameters of the reference model or of the plant are used.

Moreover, this paper presents the equivalent parameter adaptation of this method. The results of computer simulation of the adaptive control applied to a stable plant and to an unstable plant are included to illustrate the effectiveness of the proposed method.

\section{1. 緒言}

プラントの特性が未知で, 目標值, 外乱あるいは経 時により変化する場合には，その特性をたえず認知し て制御装置の特性を所期の目的を満たすように変化さ せる制御，すなわち適応制御を行うととが必要であ る.

適応制御に関しては，乙れまでいろいろな手法が提 案されている112). そのなかで，モデル規範形適応制 御方式は不変, あるいはゆっくりと変化する未知パラ メータを含むプラントの制御に対し有力な手段を与え る. それは, プラントに対し, その動作の手本となる

\footnotetext{
†第 21 回自動制御連合講演会で発表（昭 53.11）

* 名古屋工業大学工学部 名古屋市昭和区御器所町

* Faculty of Engineering, Nagoya Institute of Technology, Nagoya

(Received March 3, 1980)

(Revised May 12, 1980)
}

系すなわち規範モデルを用意して，両者の応答が一致 するように適応制御を行うものである. その制御法に は二つの基本的な考え方がある ${ }^{21}$. 一つはパラメータ 適応とよばれ，プラントの可調整パラメータまたはプ ラントに付加された可変パラメータを調整するすの で，他の一つは信号合成適応とよばれ，プラントへの 入力を調整するものである.いずれも測定可能な信号 のみを用いて，制御系の安定性が保証された調整則を 作ることが望ましい，一般の系に执いて，規範モデル のすべてのパラメータに対芯してプラント側のパラメ 一タを可調整にするように構成し，安定な設計法を確 立するととは一般に困難であるので, 後者の手法が現 在ではより実際的で融通性のある設計法とみなされ， 主流をなしている。

一般に適応制御系においては，制御装置はかなり複 雑な動作が要求されるので, ディジタル計算機を用い るととになる．したがって連続時間で動作するプラン トを離散化したものに対して，離散時間形式の適応制 御系を設計する必要がある。適応制御系は一般に非線 形で時変系であるととにより，連続時間形式の適応制 御の設計結果をそのまま離散時間系へ適用するととは できない，別に安定性の保証された離散時間形式のモ デル規範形適応制御系の設計法を確立する必要があ る.

信号合成適応によるとの種の設計法の研究がすでに

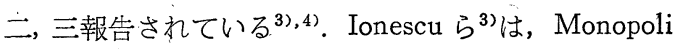
の提案した拡張誤差を用いる連続時間形式の適応制御 系の設計法を離散時間領域で Liapunov の安定論に基 づいて論じている: 鈴木ら出むこれと同種の問題を Popov の超安定論を用いて論じている. しかしいず れの論文に抬いても，系の安定性を保証するために， プラントの入力に関係する信号の有界性を仮定してい る.また前者に执いては，多くの高次のフィルタを使 用するため制御装置の構造が非常に複雑であり, 後者 においては,さらにそのアルゴリズムに拉いて 3 次代 数方程式の求解が要求される. 
本論文では, 単一入出力系に対して, Liapunov'の 安定論に基づいて, 測定可能な信号のみを用いて規範 モデルとプラントのパラメータをまったく必要としな い，離散時間モデル規範形適応制御系を信号合成適応 によって構成する一つの設計法を提案する. 乙の設計 法は体系的で, より一般的な調整則を容易に導出で き，また構造む簡潔で，しかむ多入出力系に容易に拡 張できる( ${ }^{5)}$ という利点をむっている.

以下では，本論文で扱う問題を述へ，設計の基礎と なる出力誤差に関する方程式を導く.つぎにての方程 式に Liapunov の安定論を適用するととにより, 適 応制御系の安定性を保証するための条件および調整則 を導出する.さらに，パラメータ適応との関係を明確 にする. 最後に，乙てに提案する適応制御法の有效性 を示すために，計算機シミュレーションの結果を述べ る.

\section{2. 問題の設定}

こてでは, $n$ 次の単一入出力の伝達関数が $s$ の右半 面に零点をむたない，連続時間集中定数線形系(以下， ここではこれを略して連続時間系とよぶ) でモデル化 できるプラントを，ディジタル計算機を制御装置に用 いて離散時間で適応制御を行う場合を考える.したが って, プラントを，その連続時間系の入力側ヘサンプ ラと零次ホールド回路を前置し, 出力側にサンプラを 後置してえられる離散時間系で記述する。以下, 連続 時間系での Krishnan の方法 ${ }^{6)}$ 之同様の定式化を進め るが，離散時間系であるためのいくつかの創意工夫を 行っている. いま，その離散時間系が可観測であると き,つぎの Lüders-Narendra の正集形》に書くこと ができる.

$$
\begin{aligned}
& \boldsymbol{x}_{p}(k+1)=\boldsymbol{A}_{p} \boldsymbol{x}_{p}(k)+\boldsymbol{b}_{p} u(k) \\
& y_{p}(k)=\boldsymbol{c}_{p}{ }^{T} \boldsymbol{x}_{p}(k)
\end{aligned}
$$

ここで,

$$
\begin{aligned}
& \boldsymbol{x}_{p}{ }^{T}(k)=\left[x_{p 1}(k), x_{p 2}(k), \cdots, x_{p_{n}}(k)\right] \\
& \boldsymbol{c}_{p}{ }^{T}=[1,0, \cdots, 0] \\
& \boldsymbol{A}_{p}=\left[\begin{array}{c:ccc}
a_{p 1} & 1 & \cdots & \cdots \\
a_{p 2} & -\lambda_{2} & \mathbf{0} \\
\vdots & 0 & \ddots & \\
a_{p n} & 0 & -\lambda_{n}
\end{array}\right], \quad \boldsymbol{b}_{p}=\left[\begin{array}{c}
b_{p 1} \\
b_{p 2} \\
\vdots \\
b_{p n}
\end{array}\right]
\end{aligned}
$$

また $(\cdot)^{T}$ は $(\cdot)$ の転置を示す. 添字 $p$ はプラン 卜を示す. $x_{p}(k), u(k), y_{p}(k)$ はそれぞれ $k$ 時点にお ける $n$ 次元状態変数ベクトル, スカラー入力, スカラ 一出力である. $\boldsymbol{A}_{p}$ の要素である $\lambda_{i}(i=2, \cdots, n)$ は すべて相異なり, 絶対值が 1 より小さい既知の任意定 数である. $A_{p}$ のその他の要素 $a_{p_{i}}(i=1, \cdots n)$ およ
び $\boldsymbol{b}_{p}$ の要素 $b_{p_{i}}(i=1, \cdots, n)$ のすべては未知とする. さらに次数 $n$ はプラントの構造に関する知識より既知 であるとする.さらに(1)式のシステムは可制御とす る. そのとき $(1)$ 式の伝達関数表現はつぎになる.

$$
\begin{aligned}
Y_{p}(z) / U(z) & \\
\quad & =\boldsymbol{c}^{T}\left(z \boldsymbol{I}-\boldsymbol{A}_{p}\right)^{-1} \boldsymbol{b}_{p}=G_{p}(z) \\
& =\frac{b_{p 1}+b_{p 2} /\left(z+\lambda_{2}\right)+\cdots+b_{p_{n}} /\left(z+\lambda_{n}\right)}{z-a_{p 1}-a_{p 2} /\left(z+\lambda_{2}\right)-\cdots-a_{p n} /\left(z+\lambda_{n}\right)}
\end{aligned}
$$

こてで, $z=e^{s T}, s$ はラプラス演算子, $T$ はサンプ リング周期を示す.

(2)式より明らかなように， $b_{p 1}$ は， $u(k)$ に単位ス テップ入力をいれたときの $k=1$ 時点における出力 $y_{p}(k)$ の值を与える. 零次ホールド回路と組み合わさ れた連続時間系の離散時間表現においては， $b_{p 1} \neq 0$ で ある. それゆえ, $G_{p}(z)$ の分母, 分子の $z$ の次数差 は, 実現可能な連続時間系の伝達関数における分母, 分子の $s$ の次数差にかかわらず，つねに 1 になるとと に注意する.

ここで, $G_{p}(z)$ の零点はすべて $z$ 平面上の単位円内 にあるものとする．てれは，のちに述べるようにプラ ントの入力 $u(k)$ を有界にするための十分条件として 必要である.

(1)式で与えられるプラントに対して, 同じ構造と 次元をむつ，つぎの規範モ゙デルを考える.

$$
\begin{aligned}
& \boldsymbol{x}_{m}(k+1)=\boldsymbol{A}_{m} \boldsymbol{x}_{m}(k)+\boldsymbol{b}_{m} r(k) \\
& y_{m}(k)=\boldsymbol{c}_{m}{ }^{T} \boldsymbol{x}_{m}(k)
\end{aligned}
$$

ここで

$$
\begin{aligned}
& \boldsymbol{x}_{m}{ }^{T}(k)=\left[x_{m 1}(k), x_{m 2}(k), \cdots, x_{m n}(k)\right] \\
& \boldsymbol{c}_{m}{ }^{T}=[1,0, \cdots, 0]
\end{aligned}
$$

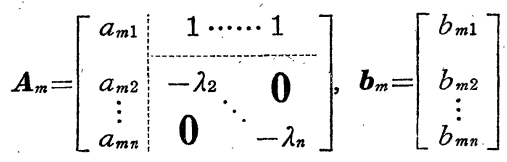

添字 $m$ はモデルを示す. $\quad r(k)$ はモデルへのスカラ 一入力で有界であり，またモデルは宛定とする．

モデルのパラメータ $a_{m i}, b_{m i}(i=1, \cdots, n)$ は通常既 知であるが; モデルがパラメータ未知の機械で与えら れ，プラントがその応答を規範とする場合を考慮し て，以下に述べる設計法では未知として取り扱う。す ち万ん既知の場合には，その結果を容易に変更し簡単 化できる (後章参照).

ここで考えるモデル規範形適応制御の目的は, 適応 速度に比べて未知パラメータの変動速度がおるい場合 に, プラントの出力 $y_{p}(k)$ を, その入力 $u(k)$ を測定 可能な信号のみを用いて適応的に調整して，理想的な 応答であるモデルの出力 $y_{m}(k)$ に追従させるととであ 
る.

\section{3. 誤差方程式の導出}

状態誤差を

$$
e_{i}(k)=x_{m i}(k)-x_{p_{i}}(k), \quad i=1, \cdots, n
$$

と定めると, (3.a)式より (1.a)式を差し引いて, 各状 態誤差について次式をうる.

$$
\begin{aligned}
e_{1}(k+1)= & a_{m 1} e_{1}(k)+d_{1} x_{p 1}(k)+b_{m 1} r(k) \\
& -b_{p 1} u(k)+\sum_{i=2}^{n} e_{i}(k) \\
e_{i}(k+1)= & -\lambda_{i} e_{i}(k)+a_{m i} e_{1}(k)+d_{i} y_{p}(k) \\
& +b_{m i} r(k)-b_{p_{i}} u(k) \quad i=2, \cdots, n(6)
\end{aligned}
$$

ただし， $d_{i}=a_{m i}-a_{p_{i}}, \quad i=1, \cdots, n$

(5)式の $e_{i}(k)(i=2, \cdots, n)$ を消去するために, 次 式の 1 次フィルタから発生される補助信号 $p_{i}(k)$, $q_{i}(k), \quad v_{i}(k), w_{i}(k)(i=2, \cdots, n)$ を導入する.

$$
\left.\begin{array}{l}
p_{i}(k+1)=-\lambda_{i} p_{i}(k)+K_{1 i} e_{1}(k) \\
q_{i}(k+1)=-\lambda_{i} q_{i}(k)+K_{2 i} y_{p}(k) \\
v_{i}(k+1)=-\lambda_{i} v_{i}(k)+K_{3 i} r(k) \\
w_{i}(k+1)=-\lambda_{i} w_{i}(k)-K_{4 i} u(k)
\end{array}\right\}
$$

ただし， $K_{j i}(i=2, \cdots, n, j=1, \cdots, 4)$ は零でない任 意定数である.

(5)〜 ( 7) 式より $e_{i}(k)$ を消去するとつぎの結果を う.

$$
\begin{aligned}
e_{1}(k+1)= & a_{m 1} e_{1}(k)+d_{1} y_{p}(k)+b_{m 1} r(k)-b_{p_{1}} u(k) \\
& +\sum_{i=2}^{n}\left\{a_{m i} p_{i}(k) / K_{1 i}+d_{i} q_{i}(k) / K_{2 i}\right. \\
& \left.+b_{m i} v_{i}(k) / K_{3 i}+b_{p_{i}} w_{i}(k) / K_{4 i}\right\}+h(k)
\end{aligned}
$$

ただし，

$$
\begin{aligned}
h(k)= & \sum_{i=2}^{n}\left(-\lambda_{i}\right)^{k}\left\{e_{i}(0)-a_{m i} p_{i}(0) / K_{1 i}\right. \\
& -d_{i} q_{i}(0) / K_{2 i}-b_{m i} v_{i}(0) / K_{3 i} \\
& \left.-b_{p_{i}} w_{i}(0) / K_{4 i}\right\}
\end{aligned}
$$

$h(k)$ は出力誤差 $e_{1}(0)$ を除く状態誤差と補助信号 の初期值からなっており， $\left|\lambda_{i}\right|<1(i=2, \cdots, n)$ より $k \rightarrow \infty$ で零となる.

つぎに，プラントの入力 $u(k)$ を測定可能な信号の みを用いて，つぎのように発生させる.

$$
\begin{aligned}
u(k)= & {\left[\theta_{1}(k) e_{1}(k)+\phi_{1}(k) y_{p}(k)+\phi_{1}(k) r(k)\right.} \\
& +\eta_{1}(k) e_{1}(k-1)+\sum_{i=2}^{n}\left\{\theta_{i}(k) p_{i}(k)\right. \\
& +\phi_{i}(k) q_{i}(k)+\phi_{i}(k) v_{i}(k) \\
& \left.\left.+\eta_{i}(k) w_{i}(k)\right\}\right] / \pi(k) .
\end{aligned}
$$

ここで, $\theta_{i}(k), \phi_{i}(k), \phi_{i}(k), \eta_{i}(k)(i=1, \cdots, n)$ および $\pi(k)$ は $(4 n+1)$ 個の適応ゲインで, 次章で述
ベる調整則によって定める.

(10)式を(8)式に代入して整理し, その結果の式に $e_{1}$ に関して PID 動作(注 1).を実現するために, 両迅 に $\alpha e_{1}(k)+\beta e_{1}(k-1)$ (設計パラメータ $\alpha, \beta$ の定め 方はのちに述べる) を加えると次式をうる.

$$
\begin{aligned}
& \tilde{e}_{1}(k+1)=\boldsymbol{r}^{T}(k) \boldsymbol{\delta}(k)+h(k) \\
& \text { ただし， } \\
& \tilde{e}_{1}(k+1)=e_{1}(k+1)+\alpha e_{1}(k)+\beta e_{1}(k-1) \\
& r^{T}(k)=\left[a_{m 1}+\alpha-\theta_{1}(k), d_{1}-\phi_{1}(k), b_{m 1}-\phi_{1}(k),\right. \\
& \beta-\eta_{1}(k), \quad a_{m 2} / K_{12}-\theta_{2}(k), \cdots, a_{m n} / K_{1 n} \\
& -\theta_{n}(k), \quad d_{2} / K_{22}-\phi_{2}(k), \cdots, d_{n} / K_{2 n} \\
& -\phi_{n}(k), \quad b_{m 2} / K_{32}-\phi_{2}(k), \cdots, b_{m n} / K_{3 n} \\
& -\phi_{n}(k), \quad b_{p 2} / K_{42}-\eta_{2}(k), \cdots, b_{p_{n}} / K_{4 n} \\
& \left.-\eta_{n}(k), \pi(k)-b_{p 1}\right] \\
& \left.w_{2}(k), \cdots, w_{n}(k), u(k)\right]
\end{aligned}
$$

(12)〜 (14) 式はそれぞれスカラー $\tilde{e}_{1}(k+1),(4 n+1)$ 次元ベクトルの未知パラメータと適応ゲインからなる $\boldsymbol{r}(k)$ ，および測定可能な信号からなる $\delta(k)$ を示 す(注 2).

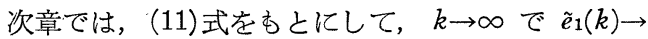
0 を保証するための $\boldsymbol{r}(k)$ すなわち適応ゲイン $\theta_{i}(k)$, $\phi_{i}(k), \quad \phi_{i}(k), \eta_{i}(k)(i=1, \cdots, n)$ および $\pi(k)$ の調整 則と条件を求める．そのとき，(12)式において， $\alpha, \beta$ を多項式 $z^{2}+\alpha z+\beta$ が安定よなるように選べば $k \rightarrow$ $\infty$ で $e_{1}(k) \rightarrow 0$ をうる.

\section{4. 適応制御系の設計}

適応ゲインの調整則に関連して，つぎのことがいえ る.

$$
\begin{aligned}
& (11) \text { 式のシステムは, } \boldsymbol{r}(k) \text { を } \\
& \boldsymbol{r}(k)=\boldsymbol{r}(k-1)-\varepsilon(k) \tilde{e}_{1}(k) \boldsymbol{\delta}(k-1) \\
& \varepsilon(k)=\rho /\left[\boldsymbol{\delta}^{T}(k-1) \boldsymbol{\delta}(k-1)\right] . \quad 0<\rho<2
\end{aligned}
$$

に従って調整することにより， $k \rightarrow \infty$ で $\tilde{e}_{1}(k) \rightarrow 0$ す なわち $e_{1}(k) \rightarrow 0$ にするととができる.（証明とその条 件については次章で述べる。なお，文献 8 に示されて

$$
\begin{aligned}
& \text { (i注 1) } \begin{aligned}
\boldsymbol{e}_{1}(k+1)+\alpha e_{1}(k)+\beta e_{1}(k-1) \\
=\left[e_{1}(k+1)+\alpha^{\prime}\left\{e_{1}(k+1)-e_{1}(k)\right\}+\beta^{\prime}\left\{e_{1}(k+1)\right.\right. \\
\left.\left.-2 e_{1}(k)+e_{1}(k-1)\right\}\right] /\left(1+\alpha^{\prime}+\beta^{\prime}\right)
\end{aligned} \\
& \text { ただし, } \alpha=-\left(\alpha^{\prime}+2 \beta^{\prime}\right) /\left(1+\alpha^{\prime}+\beta^{\prime}\right) \\
& \quad \beta=\beta^{\prime} /\left(1+\alpha^{\prime}+\beta^{\prime}\right)
\end{aligned}
$$

(注 2) $\beta$ は通常, 既知の設計パラメータであり, $\eta_{1}(k) \equiv \beta$ として固定することができるが，後述のように，十分 一般的でない規範入力では $r=0$ とならないために, $\eta_{1}(k)$ を適応ゲインとして調整するととにより，制御 系の過渡特性の改善を図るととを考慮して，他のパラ メータと同様，ここでは統一的に报っている. 


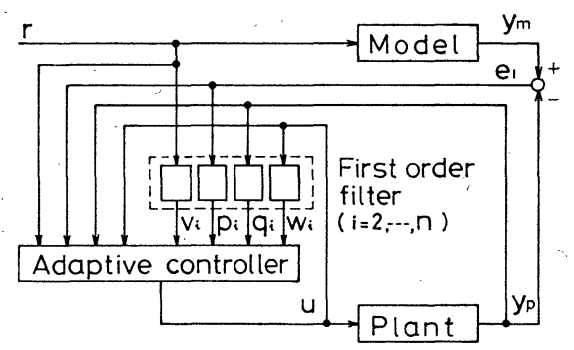

Fig. 1 Schematic diagram of the model reference adaptive control system

いる，より一般の調整則に対してあ成立する.)

(15) 式は $(4 n+1)$ 個の適応ゲインの調整則について 書き直すとつぎになる。

$$
\begin{aligned}
& \theta_{1}(k)=\theta_{1}(k-1)+\varepsilon(k) \tilde{e}_{1}(k) e_{1}(k-1) \\
& \phi_{1}(k)=\phi_{1}(k-1)+\varepsilon(k) \tilde{e}_{1}(k) y_{p}(k-1) \\
& \phi_{1}(k)=\phi_{1}(k-1)+\varepsilon(k) \tilde{e}_{1}(k) r(k-1) \\
& \eta_{1}(k)=\eta_{1}(k-1)+\varepsilon(k) \tilde{e}_{1}(k) e_{1}(k-2) \\
& \theta_{i}(k)=\theta_{i}(k-1)+\varepsilon(k) \tilde{e}_{1}(k) p_{i}(k-1) \\
& \phi_{i}(k)=\phi_{i}(k-1)+\varepsilon(k) \tilde{e}_{1}(k) q_{i}(k-1) \\
& \phi_{i}(k)=\phi_{i}(k-1)+\varepsilon(k) \tilde{e}_{1}(k) v_{i}(k-1) \\
& \eta_{i}(k)=\eta_{i}(k-1)+\varepsilon(k) \tilde{e}_{1}(k) w_{i}(k-1) \\
& \pi(k)=\pi(k-1)-\varepsilon(k) \tilde{e}_{1}(k) u(k-1)
\end{aligned} \quad i=2, \cdots, n
$$

Fig. 1 に，上述した測定可能な信号のみを用いた 信号合成適応によって構成する，モデル規範形適応制 御系の概略を示す.

規範モデルのパラメータが既知である場合には， (17) 式中の適応ゲイン $\theta_{i}, \phi_{i}(i=1, \cdots, n)$ と $\eta_{1}$ をつ ぎの值に固定して, $2 n$ 個の適応ゲインについての調 整則を構成すればょい.

$$
\left.\begin{array}{l}
\theta_{1}=a_{m 1}+\alpha, \quad \phi_{1}=b_{m 1}, \quad \eta_{1}=\beta \\
\theta_{i}=a_{m i} / K_{1 i}, \quad \phi_{i}=b_{m i} / K_{3 i} \quad(i=2, \cdots, n)
\end{array}\right\}
$$

\section{5. 安定性に関する考察}

まず，(11)式において $h(k)=0$ のとき，システム が一様漸近安定な原点をもてば, $k \rightarrow \infty$ で零となる $h(k)$ を加えたシステム(11)式は, eventually asymptotically stable な原点になるととが示されている99 の で, 以下では. (11)式において $h(k)=0$ の場合のシ ステムが $k \rightarrow \infty$ で $\tilde{e}_{1}(k) \rightarrow 0$ になる証明と条件を与え る.

まず, $\boldsymbol{r}(k)$ に関するリアプノフ関数としてつぎの ような $V(k)$ を考える.

$$
V(k)=\boldsymbol{r}^{T}(k) \boldsymbol{r}(k)
$$

$V(k)$ の差分 $\Delta V(k)$ は，(11)，(15)，(16)式を用い てつぎになる.

$$
\Delta V(k)=V(k)-V(k-1)
$$

$$
\begin{aligned}
= & \boldsymbol{r}^{T}(k) \boldsymbol{r}(k)-\boldsymbol{r}^{T}(k-1) \boldsymbol{r}(k-1) \\
= & {\left[\boldsymbol{\gamma}^{T}(k-1)-\varepsilon(k) \tilde{e}_{1}(k) \boldsymbol{\delta}^{T}(k-1)\right] } \\
& \times\left[\boldsymbol{r}(k-1)-\varepsilon(k) \tilde{e}_{1}(k) \boldsymbol{\delta}(k-1)\right] \\
& -\boldsymbol{r}^{T}(k-1) \boldsymbol{r}(k-1) \\
= & -\varepsilon(k)\left[2-\varepsilon(k) \boldsymbol{\delta}^{T}(k-1) \boldsymbol{\delta}(k-1)\right] \tilde{e}_{1}{ }^{2}(k) \\
= & -\rho(2-\rho) \tilde{e}_{1}{ }^{2}(k) /\left[\boldsymbol{\delta}^{T}(k-1) \boldsymbol{\delta}(k-1)\right] \leqq 0
\end{aligned}
$$

$\Delta V(k)$ は有限時間発散が起こらなりれば準負定で あり，つぎの 3 通りの場合に零となる。

(1) $\|\boldsymbol{d}\|$ が有界で, $\tilde{e}_{1}=0$ の場合

(2) $\|\boldsymbol{\delta}\|$ が無限大で, $\tilde{e}_{1}$ が有界である場合

(3) $\|\boldsymbol{\delta}\|,\left|\tilde{e}_{1}\right|$ がとむに無限大で, $\|\boldsymbol{\delta}\|$ の無限大 への移行が . $\left|\tilde{e}_{1}\right|$ のそれより速い場合

いずれの場合む, $k \rightarrow \infty$ で $\Delta V(k) \rightarrow 0$ より, $V(k)$ 二一定となり， $r(k)=$ 一定に収束する．また， $r(k)$ は 有界である.

(1)の場合は, $k \rightarrow \infty$ で $e_{1 \rightarrow 0}$ となるので, 所望 の結果である.

(2)の場合について考察する. $\tilde{e}_{1}$ が有界であれば, (12)式加ら e 1 は有界となり，（4)式とrの有界性の 仮定より $y_{p}$ あ有界となる. プラントの伝達関数 $G_{p}$ $(z)$ 分母分子の次数差は 1 である. さらに $G_{p}(z)$ の零 点はすべて $z$ 面の単位円内にあるとすれば, $1 /[(z+\lambda)$ $\left.G_{p}(z)\right]$ (ただし $|\lambda|<1$ とする) は安定で, プロパー な伝達関数である。それゆえに, $\mathscr{Z}^{-1}\left\{1 /\left[(z+\lambda) G_{p}(z)\right]\right.$ $\left.Y_{p}(z)\right\}=\mathscr{Z}^{-1}\{1 /(z+\lambda) \cdot U(z)\}$ は有界となる（こてで, $\mathscr{Z}^{-1}$ は逆 $z$ 変換を示す). したがって, $u$ は有界であ る.

つぎに補助信号 $p_{i}, q_{i}, v_{i}, w_{i}(i=2, \cdots, n)$ は, (7) 式と $e_{1}, y_{p}, r, u$ が有界であることから有界とな る. 以上より，るは有界になる（可制御であるとき， (4), (6)式から $x_{p}$ む有界である). 結局, $r$ が有 界, $G p(z)$ の零点がすべて $z$ 面の単位円内にあれば, $\left|\tilde{e}_{1}\right|$ が有界で $\|\boldsymbol{\delta}\|$ が無限大になる解は存在せず，(2) の場合は起りえない。

（3)の場合をつぎに考察する. (20)式の $\Delta V$ の分 母, 分子は，それぞれ(12)，(14)式を用いて，プラン トの入出力がモデルのそれに比して十分大きくなった ときを考えると，つぎのように近似できる．

$$
\begin{aligned}
\rho(2-\rho) \tilde{e}_{1}{ }^{2}(k) \fallingdotseq \rho & (2-\rho)\left[y_{p}(k)+\alpha y_{p}(k-1)\right. \\
+ & \left.\beta y_{p}(k-2)\right]^{2} \\
\delta^{T}(k-1) \boldsymbol{\delta}(k-1) & \fallingdotseq 2 y_{p}{ }^{2}(k-1)+y_{p}{ }^{2}(k-2) \\
& +u^{2}(k-1)+\sum_{i=2}^{n}\left\{p_{i}{ }^{2}(k-1)\right. \\
& \left.+q_{i}{ }^{2}(k-1)+w_{i}{ }^{2}(k-1)\right\}
\end{aligned}
$$


上式はとあに，プラントの入出力のみで書き表わすて 之ができるので, $G_{p}(z)$ の零点が単位円内にあれば, すべての発散入力は消去されるてとなく出力に影響を 及ぼすので, $\Delta V$ の分母, 分子の大きさは同じオーダ である.すなわち $\Delta V$ は零とはならず, $\Delta V<c<0$ なる $c$ が存在する．したがって, $V$ 関数の初期值が有 限であることより，プラントの零点が単位円内にあれ ば( 3 ).の場合は起り得ない.

なお, 上述の証明においては, 有限時間発散が起ら ないととを仮定している，いま，ある有限な $k$ の值 $\left(k_{0}+1\right.$ とする) で, $\left|\tilde{e}_{1}\left(k_{0}+1\right)\right|$ が無限大となる有限 時間発散は, 以下に述べるようにアルゴリズムにおい て容易にさけることができる. $\left|\tilde{e}_{1}\left(k_{0}+1\right)\right|$ が無限大 となるのは，(11)式において $\boldsymbol{r}\left(k_{0}\right)$ の有界性より\|d $\left(k_{0}\right) \|$ が無限大すなわち $\left|u\left(k_{0}\right)\right|$ が無限大になるとき である. (10)式より， ある有限な $k_{0}$ で $\left|u\left(k_{0}\right)\right|$ が無 限大となるのは， $\pi\left(k_{0}\right)=0$ 以外にはない， $\pi\left(k_{0}\right)=0$ をさけるには，(17)式の $\pi$ の調整則で $\rho$ を 0 2 の 範囲で変えて, $\pi\left(k_{0}\right) \neq 0$ とすればよい（計算機シミュ レーションにおいて， $\pi$ の初期值を適当な大きさにと れば， $\pi\left(k_{0}\right)=0$ となる例を経験していないので，実 用上てれが動作するととはほとんどないと考える).

以上より， $r$ が有界, プラントの零点が単位円内に あれば， $u$ が有界で $k \rightarrow \infty$ で $\tilde{e}_{1}(k) \rightarrow 0$ となる. そし て(12)式に拈いて， $\alpha, \beta$ を多項式 $z^{2}+\alpha z+\beta$ が安定 となるように選定すれば， $k \rightarrow \infty$ で $e_{1}(k) \rightarrow 0$ を保証 する. $\alpha, \beta$ の安定条件は容易に知れるように

$$
\beta<1,1+\alpha+\beta>0,1-\alpha+\beta>0
$$
である.

\section{6. パラメータ適応との関連}

これまでの設計法において, 補助信号を用いて記述 を行ってきたが，(7)式より明らかなように補助信号 をすべて測定可能な信号によって書くことができる.

実際の計算に扰いては，補助信号を用いたほうが便利 であるが，補助信号をまったく使用しなくても制御系 の記述を行うこと办できる．とてでは，補助信号を消 去するととにより，本設計法において信号合成適応形 のモデル規範形適応制御系が, パラメータ.適応形のそ れで記述できることを示そう。

(10)式に（7)式を代入した結果（ただし，初期条件 を零とおく）を用いて，Fig. 1 の制御系は適応ゲィ ンのある一定值に対して Fig. 2 のように書くことが できる. こてで,

$$
G_{\theta}(z)=\theta_{1}+\eta_{1} / z+\sum_{i=2}^{n} K_{1 i} \theta_{i} /\left(z+\lambda_{i}\right)
$$

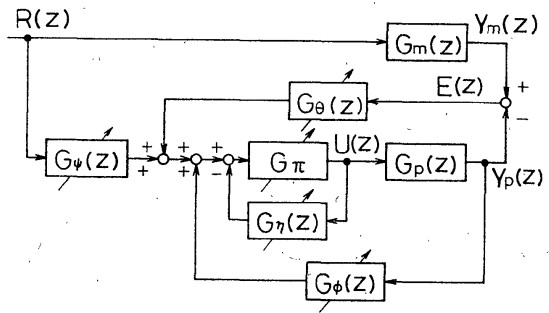

Fig. 2 Equivalent parameter adaptation representation of the input synthesis adaptation in Fig. 1

$$
\left.\begin{array}{l}
G_{\phi}(z)=\phi_{1}+\sum_{i=2}^{n} K_{2 i} \phi_{i} /\left(z+\lambda_{i}\right) \\
G_{\phi^{\prime}}(z)=\phi_{1}+\sum_{i=2}^{n} K_{3_{i}} \phi_{i} /\left(z+\lambda_{i}\right) \\
G_{\eta}(z)=\sum_{i=2}^{n} K_{4_{i}} \eta_{i} /\left(z+\lambda_{i}\right), \quad G_{\pi}=1 / \pi
\end{array}\right\}
$$

なるパルス伝達関数を示す.

適応制御は，(24)式の適応ゲインに相当するパラメ ータを調整するてとにより，プラントの出力をモデル の出力に一致させるパラメータ適応とみなすてとがで きる.ただし，モデルの伝達関数 $G_{m}(z)$ の次数に比 して, プラント側全体の伝達関数の次数が高いパラメ 一夕適応の問題となっている ${ }^{10)}$ 。すおち，Fig. 2上 り容易に $R(z)$ から $Y_{p}(z)$ までの伝達関数は,

$$
\begin{aligned}
\frac{Y p(z)}{R(z)} & =G(z) \\
& =\frac{G_{\pi} G_{p}(z)\left[G_{\phi}(z)+G_{m}(z) G_{\theta}(z)\right]}{1+G_{\pi}\left[G_{\eta}(z)+G_{p}(z)\left\{G_{\theta}(z)-G_{\phi}(z)\right\}\right]}
\end{aligned}
$$

となる. モデルの伝達関数 $G_{m}(z)$ の分母, 分子の次 数がそれでれ $n, n-1$ であるのに対し， $G(z)$ のそれ らは $3 n, 3 n-1$ となる。 モデルのパラメータが既知 のときには， $G_{\theta}, G_{\phi}$ のパラメータは固定され，時不 変の伝達関数となる.

$\gamma=0$ のとき，モデルとプラント側の伝達関数は一 致する.すなわち $G(z)=G_{m}(z)$ になる. $r$ がステッ プ信号のときには，通常 $\boldsymbol{\gamma} \neq \mathbf{0}$ であるので, 次数の一 致はえられず，ただ定常ゲィンが合うだけである.

\section{7. 数值計算例}

上述の適応制御系の動作を検討するため, 安定およ び不安定なプラントについて計算機シミュレーション を実施した：ともにつぎの 3 次系の伝達関数で記述さ れるプラントおよび規範モデルを用い，それらすべて のパラメータを未知とする調整則を用いた。 


$$
G(s)=\frac{K \sigma \omega_{n}^{2}\left(T_{1 s}+1\right)}{(s+\sigma)\left(s^{2}+2 \zeta \omega_{n} s+\omega_{n}^{2}\right)}
$$

[例 1] 安定なプラントと規範モデルに対して, (26)式の各パラメータをつぎのように選定した.

プラント: $\zeta=1.2, \omega_{n}=1.0, \sigma=1.0, T_{1}=0.333$

$$
K=1.3
$$

規範モデル : $\zeta=0.7, \omega_{n}=1.0, \sigma=1.5, T_{1}=2.0$

$$
K=1.0
$$

上記の伝達関数に零次ホールド回路を組み合わせた あのを, サンプリング周期 $T=0.2$ で離散化して, Lüders-Narendra の正準形に書き直したとき，プラ ントと規範モデルのパラメータはつぎになる.

$$
\begin{aligned}
\boldsymbol{A}_{p} & =\left[\begin{array}{rcc}
2.21 & 1 & 1 \\
4.69 & 0.13 & 0 \\
-6.17 & 0 & 0.067
\end{array}\right], \quad \boldsymbol{b}_{p}=\left[\begin{array}{c}
0.00838 \\
-0.0613 \\
0.0665
\end{array}\right] \\
\boldsymbol{A}_{m} & =\left[\begin{array}{ccc}
2.26 & 1 & 1 \\
5.32 & 0.13 & 0 \\
6.90 & 0 & 0.067
\end{array}\right], \quad \boldsymbol{b}_{m}=\left[\begin{array}{l}
0.0511 \\
0.618 \\
0.625
\end{array}\right]
\end{aligned}
$$

ただし， $\lambda_{2}=-0.13, \lambda_{3}=-0.067$ と選んだ。

さらに，規範入力としては， $r(k)=1$ なる単位ステ ップ信号を用いた. Fig. 3 にシミュレーション結果 を示す. この例では設計パラメータとしてつぎの值を 用いた。

$$
\begin{aligned}
& \rho=1.0, \quad \alpha^{\prime}=40(\alpha=-1.58), \quad \beta^{\prime}=60(\beta=0.594), \\
& \pi(0)=0.025, \quad K_{1 i}=K_{2 i}=K_{3 i}=10, \quad K_{4 i}=0.1 \\
& (i=2,3)
\end{aligned}
$$

適応ゲイン， 補助信号，プラントおよびモデルの状 態変数の初期值はすべて零としている. Fig. 3 の白丸 はモデルの出力, 黒丸はプラントの出力, 実線はプラ ントの単位ステップ応答を示す. プラントの出力は規 範モデルの出力によく追従しており, 適応制御系とし

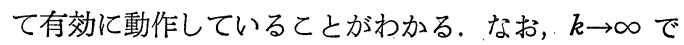
$e_{1} \rightarrow 0$ であるが, $r \rightarrow 0$ とはならない.

[例 2] プラントが不安定である場合である.

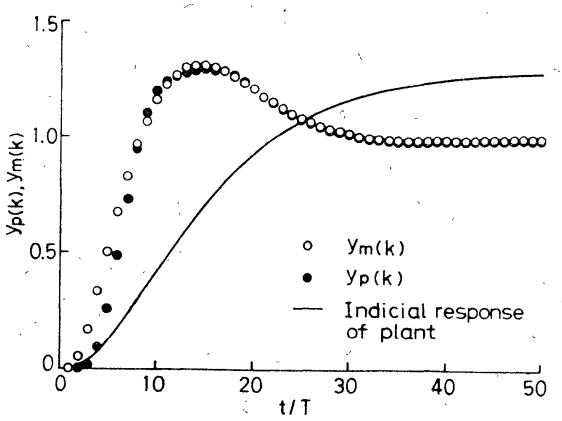

Fig. 3 Simulation results for a stable third order plant

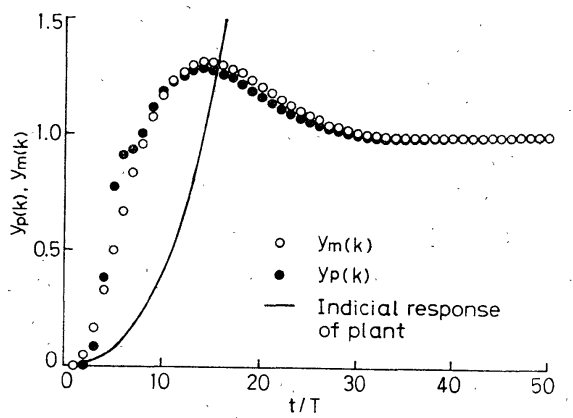

Fig. 4 Simulation results for an unstable third order plant

式におけるプラントの各パラメータをつぎに示す.

$\zeta=-1.2, \omega_{n}=0.3, \quad \sigma=5.0, \quad T_{1}=0.5, K=1.3$ また，規範モデルのパラメータは例 1 と同じである.

離散時間形式の正準形のパラメータはつぎになる。

$$
\begin{array}{ll}
\boldsymbol{A}_{p}=\left[\begin{array}{ccc}
1.42 & 1 & 1 \\
-0.183 & 0.2 & 0 \\
-0.0220 & 0 & 0.9
\end{array}\right], \quad \boldsymbol{b}_{p}=\left[\begin{array}{c}
0.00518 \\
0.00370 \\
0.00300
\end{array}\right] \\
\boldsymbol{A}_{m}=\left[\begin{array}{ccc}
1.36 & 1 & 1 \\
-0.349 & 0.2 & 0 \\
0.00384 & 0 & 0.9
\end{array}\right], \quad \boldsymbol{b}_{m}=\left[\begin{array}{c}
0.0511 \\
0.0542 \\
-0.000619
\end{array}\right]
\end{array}
$$

ただし， $\lambda_{1}=-0.2, \lambda_{2}=-0.9$ に選んである.

規範入力としては， $r(k)=1$ なる単位ステップ信号 を用いた. Fig. 4 にシミュレーション結果を示す. 設計パラメータはつぎの值を用いた。

$$
\begin{aligned}
& \rho=1.0, \quad \alpha^{\prime}=3.0(\alpha=-9 / 7), \quad \beta^{\prime}=3.0(\beta=3 / 7), \\
& \pi(0)=0.003, \quad K_{1 i}=K_{2 i}=K_{3 i}=10, \quad K_{4 i}=0.5 \\
& (i=2,3)
\end{aligned}
$$

各信号の初期值は例 1 と同様に，すべて零とおい た. プラントが不安定であるにあかかわらず，その出 力は安定化して規範モデルの出力によく追従している ことがわかる．なお，例 $1 ， 2$ に対して規範入力 $r$ に 多段ステップ信号を入れた場合む行ったが，良好な結 果をえている.

モデルのパラメータを既知として簡単化された調整 則を用いた場合に対するシミュレーションも行った。 設計パラメータ值は異なるが，ほとんど同様な結果を えた。

\section{8. 結言}

単一入出力の連続時間集中定数線形系を計算機制御 する，離散時間形式のモデル規範形適応制御系の一設 計法を示した. 特に Liapunov の安定論に基づき, 離 散時間形式の適応制御系の安定性の考察を行い，十分 条件を明確にした。 またパラメータ適応との関連を考 
察した. 本設計法によれば, 規範モデルとプラントの パラメータをまったく必要としないで, 現時点までの 湘定可能な信号のみを用い，プラントへの入力を信号 合成適応させることができる.

なお，設計パラメータの最適選定法は今後の重要な 研究課題である. さらに, 本手法の多入出力系への拡 張と, 実プラントへの応用については, 別に報告する 予定である.

\section{参考 文献}

1) I. D. Landau: A Survey of Model Reference Adaptive Techniques-Theory and Applications, Automatica, 10-4, 353/379 (1974)

2). 小林: モデル規範形適応制御系, 計測と制 御, 17-8, $602 / 612$ (1973)

3) T. Ionescu and R. V. Monopoli: Discrete Model Reference Adaptive Control with an Augmented Error Signal, Automatica, 13-5, 507/517 (1977)
4）鈴木, 高島 : 超安定離散時間モデル規範形適応制御系の 設計，計測自動制御学会論文集，13-5, 433/438 (1977)

5) 藤井, 柴田, 水野, 後藤: 多変数離散時間モデル規範形 適応制御系の一設計法とその応用, 第 8 回制御理諭シン ポジゥム資料，53/56 (1979)

6) K. R. Krishnan: Adaptive Model-Reference Control of an Unknown Plant with Limitted Knowledge of Model, IEEE Trans. on Automatic Control, AC22-3, 484/486 (1977)

7) G. Lüders and K.S. Narendra: An Adaptive Observer and Identifier for a Linear System, IEEE Trans. on Automatic Control, AC-18-5, 496/499(1973)

8) P. Kudva and K.S. Narendra: An Identification Procedure for Discrete Multivariable Systems, IEEE Trans, on Automatic Control, AC-19-5, 549/ 552 (1974)

9) J.P. Lasalle and R. J. Rath: Eventual Stability, Proc. 2nd Congr. IFAC, 415, 1/4 (1963)

10）伊藤：適応制御系におけるパラメータ可調整，計測と制 御, 8-4, 240/246 (1969) 